\title{
Inactive Comment
}

National Cancer Institute

\section{Source}

National Cancer Institute. Inactive Comment. NCI Thesaurus. Code C93578.

Additional description why an entity is no longer active. 